\title{
Mer enn bare gode historier
}

\author{
Hvordan kan samfunnsvitenskapen bidra med et konstruktivt og kritisk perspektiv i norsk forskning innen \\ global helse?
}

Katerini T. Storeng

katerini.storeng@sum.uio.no

«Forskningen deres er så interessant. Hvis dere bare kunne gjøre det på vår måte», sa en norsk toppforsker i global helse til en antropologkollega av meg nylig. Slik implisitt kritikk av kvalitativ forskning er vanlig fra medisinsk og helsefaglig hold.

Internasjonalt fikk debatten om kvalitativ forskning nytt liv da et utdrag fra et refusjonsbrev fra det prestisjetunge britiske tidsskriftet $B M J$ ble lagt ut på Twitter i fjor høst. «Takk for at dere sendte oss artikkelen deres», skrev redaktørene. «Vi leste den med interesse, men beklager at kvalitative studier er ekstremt lavt prioritert hos $B M J$. Vår forskning viser at slike studier ikke er like ofte lest, lastet ned eller sitert som annen forskning.» I den opphetede debatten som fulgte skrev 76 seniorforskere fra 11 forskjellige land under på et brev til $B M J_{\mathrm{s}}$ redaktører der de etterlyste et mer åpent syn på kvalitativ forskning (1). Responsen var lunken.

Hvorfor er de som driver med kvalitativ forskning så opptatt av å publisere i et medisinsk tidsskrift som $B M J$ når det tross alt finnes hundrevis av andre tidsskrifter de kan publisere i? Den tidligere $B M J$-redaktøren Richard Smith foreslår at svaret er at de er drevet av finansielle og andre incentiver knyttet til publisering $\mathrm{i}$ høyt rangerte tidsskrifter (2). Jeg tror at minst like viktig er disse forskernes oppriktige interesse for å bidra til kunnskapsbasert bedring av helsetiltak og deres ønske om å bringe et kritisk, men konstruktivt perspektiv inn i helseforskningen (3).

\section{Kvalitative metoder og samfunnsvitenskapelig teori} Ironisk nok var det nettopp $B M J$ som, for nesten 15 år siden, publiserte en av de mest klarsynte og mest siterte artiklene om hvordan kvalitative innspill kan berike helseforskningen. Helen Lambert \& Chris McKevitt, antropologer ved ledende folkehelseinstitutter i Storbritannia, påpekte at alle forsøk på å få mer aksept for kvalitativ forskning innen helsefagene har ført til feil- slått vektlegging av kvalitetskontroll og et kunstig skille mellom metode og teori, mellom teknikk og konsept (4). De argumenterte for at reell tverrfaglig forskning innebærer at man tar til seg teoretiske, ikke bare metodologiske innspill fra andre disipliner.

Selv om det utvilsomt har vært en positiv utvikling innen tverrfaglig forskning, er det dessverre slik at helseforskning fremdeles nesten utelukkende vurderes ut fra metoden som er brukt, heller enn ut fra spørsmålet som blir stilt eller kvaliteten på analysen. God tverrfaglig forskning er fortsatt ikke vanlig, og kvalitative og kvantitative funn er sjelden integrert innenfor samme analyse (5)

Mangelen på tverrfaglighet skyldes ikke bare at kvalitativ forskning har lavere status enn kvantitativ og eksperimentell forskning, men også samfunnsviternes manglende forståelse og engasjement for disse metodene. Mange antropologer synes å være overbevist om at deres tilnærming nærmest er uforenlig med helsefaglige disipliner som for eksempel epidemiologi (6). De ser derfor ikke at epidemiologien har svært mye til felles med antropologien når det kommer til interessen for å forstå hvordan helse og sykdom er påvirket av menneskers fysiske, sosiale og kulturelle miljø.

\section{Global helse og samfunnsvitenskap}

Innen feltet global helse har forskning på helsepolitikk og helsesystemer (health policy and systems research) de siste årene etablert seg som et eget felt, med vekt på hvordan lavinntekts- og mellominntektsland innretter seg for å oppnå kollektive helsemål. I den forbindelse har flere insistert på at et samfunnsvitenskapelig perspektiv er viktig for å utfordre medisinske og teknokratiske tolkninger av helsesystemer og helsepolitikk (7). Dette har bidratt til økt interesse for mitt eget fagfelt, medisinsk antropologi (en gren av sosialantropologien), som sammen med samfunnsmedisin er en retning der man tradisjonelt har hatt et sterkt analytisk søkelys på sosiale og politiske helsedeterminanter (8).

Siden 1970-årene har medisinske antropologer dokumentert hvordan helsesystemer utformes innen og gjenspeiler større historiske, økonomiske og politiske tendenser. Man har belyst hvordan global helsepolitikk og ulike programmer påvirker menneskers tilgang til helsetjenester og deres opplevelse av helse og sykdom. Selv om antropologer som oftest legger vekt på det lokale, er det økende faglig interesse for å analysere det globale helsefeltet som kulturelt system - med ny, spennende forskning på maktforhold, kunnskapsproduksjon og de store endringene innen globalt styresett for helse.

Utfordringen nå er å få antropologer og andre samfunnsvitere til å bevege seg utenfor sine egne fagfelter og dra nytte av det handlingsrommet som finnes for å utvikle en tverrfaglig forskningskultur som gjenspeiler grunnleggende samfunnsvitenskapelige problemstillinger rundt makt, institusjoner og sosial ulikhet (9).

\section{Gode forutsetninger for norsk tverrfaglighet}

Her i landet har vi gode forutsetninger for å utvikle en mer tverrfaglig forskningskultur innen global helse. Norges forskningsråds program for helse- og vaksinasjonsforskning har til nå hatt gode finansieringsordninger, det gjelder også samfunnsvitenskapelige prosjekter og arrangementer. Denne finansieringen gjorde det for eksempel mulig for en gruppe norske antropologer og deres internasjonale samarbeidspartnere å møtes for å utarbeide et felles skriveprosjekt om etnografiske studier av helsesystemer.

Resultatet var et spesialnummer av tidsskriftet Global Public Health (10), som publiserer forskning innen miljø og helse, epidemiologi, helsepolitikk og samfunnsfag rettet mot medisin og helse. I åtte originalartikler drøftet vi forholdet mellom politikk, diskurs og praksis og analyserte perspektivene til en rekke forskjellige aktører - fra pasienter i Mongolia til helsearbeidere på landsbygda i India, leger i Kenya, ansatte i ikke-statlige organisasjoner (non-governmental organizations, NGO), helsebyråkrater i Burkina Faso og Gambia og representanter for globale helsesatsinger som vaksinealliansen GAVI.

Det er også mange pågående prosjekter i Norge der man har en samfunnsvitenskapelig og historisk tilnærming til globale helsetemaer - alt fra sivilsamfunnsorganisasjoners rolle i utforming og implementering av global helsepolitikk til implementering 


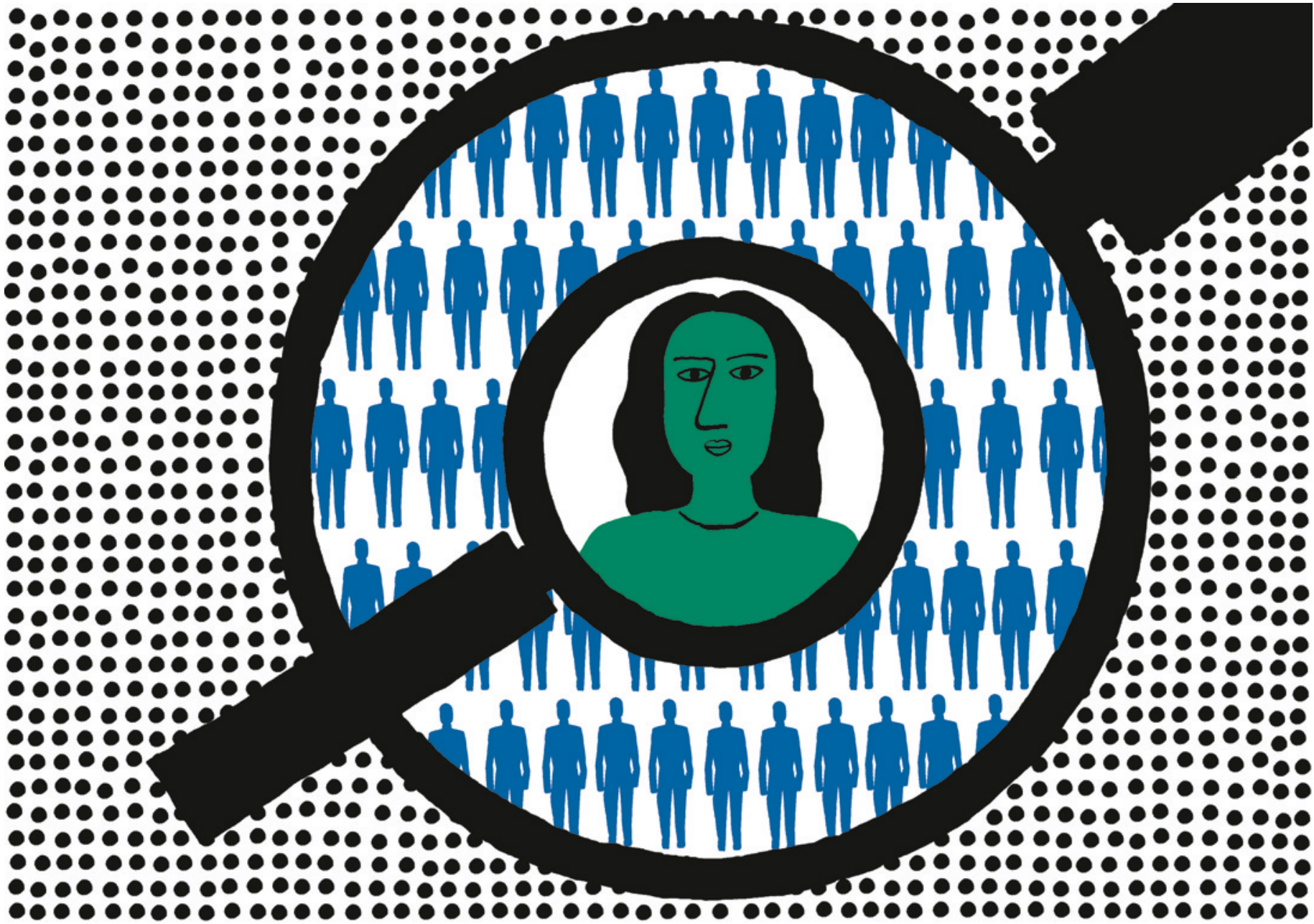

Illustrasjon: Espen Friberg

av resultatbasert finansiering i Tanzania, surrogati i India og tuberkulose, mental helse og tradisjonell medisin i Øst-Afrika og India, for å nevne noen eksempler.

Nye forskergrupper er blitt dannet det siste året, for eksempel gruppen Global helse, politikk og kultur ved min egen institusjon Senter for utvikling og miljø ved Universitetet i Oslo og Oslo-gruppen for global helsepolitikk ved Institutt for helse og samfunn, også Universitetet i Oslo. I tillegg er et nytt senter for global helse etablert ved samme institusjon. Universitetene i Oslo, Trondheim, Bergen og Tromsø har, i samarbeid med Folkehelseinstituttet, nylig lansert en nasjonal forskerskole i global helse, som vil gjøre det lettere for doktorgradsstipendiater å tilegne seg tverrfaglige ferdigheter.

Slike initiativer er tegn på at samfunnsvitenskapelige perspektiver i tiden fremover vil få større betydning innen norsk global helseforskning. For å realisere denne ambisjonen må vi samfunnsvitere bli bedre på å formidle hvorfor forskningen vår er relevant også utenfor våre egne fagmiljøer. Som helseforskere må vi bli bedre på å legge forholdene til rette for bredere forståelse av og samarbeid på tvers av forskjellige fagdisipliner.

Det er i så måte oppmuntrende at Norsk forum for global helseforskning tidligere $i$ år har støttet lanseringen av et nytt nettverk for samfunnsvitenskap i norsk global helseforskning. Det har som formål å bidra til bedre tverrfaglig utveksling og forståelse, og i løpet av sine første to uker fikk det over 100 medlemmer fra institusjoner over hele landet (11).

\section{Mer enn bare gode historier}

På fagkonferanser får vi antropologer ofte høre at våre fortellinger fra feltarbeid er et fargerikt innslag blant ellers tørre forskningspresentasjoner preget av tall og grafer. Jeg mener at verdien av en samfunnsvitenskapelig forskningstilnærming er mye større enn formidling av den menneskelige historien bak tallene.

Det handler om å stille utfordrende og ubehagelige spørsmål om sannheter vi tar for gitt. Det handler om å utfordre den teknokratiske orienteringen i mye global helseforskning og politikk for å forhindre at debatter som egentlig handler om ideologi og politiske prioriteringer, blir redusert til tekniske diskusjoner om intervensjonsstrategier og kostnadseffektivitet. Kort sagt handler det om å rette søkelyset på global helse som politikk.

Denne kronikken er basert på en nøkkelforelesning på konferansen Norwegian global health networks with impact, som fant sted 20. og 21. april 2016 i Bergen.

\section{Katerini Storeng (f. 1978)}

er ph.d., medisinsk antropolog og forsker på globale helseinitiativer og sivilsamfunnets rolle innen globalt styresett for helse. Hun er førsteamanuensis ved Senter for utvikling og miljø. Universitetet i Oslo.

Forfatter har fylt ut ICMJE-skjemaet og oppgir ingen interessekonflikter. 


\section{Litteratur}

1. Greenhalgh T, Annandale E, Ashcroft R et al. An open letter to The BMJ editors on qualitative research. BMJ 2016; 352: i563.

2. Smith R. Qualitative research and The BMJ hidden motives. The BMJ Blog 23.2.2016.

http://blogs.bmj.com/bmj/2016/02/23/

richard-smith-qualitative-research-and-the-bmjhidden-motives/ (4.10.2016).

3. Daniels K, Loewenson R, George A et al. Fair publication of qualitative research in health systems: a call by health policy and systems researchers. Int J Equity Health 2016; 15: 98.

4. Lambert H, McKevitt C. Anthropology in health research: from qualitative methods to multidisciplinarity. BMJ 2002; 325: 210-3.

5. Lewin S, Glenton C, Oxman AD. Use of qualitative methods alongside randomised controlled trials of complex healthcare interventions: methodological study. BMJ 2009; 339: b3496.

6. Inhorn MC. Medical anthropology and epidemiology: divergences or convergences? Soc Sci Med 1995; 40: 285-90.
7. Gilson L, Hanson K, Sheikh K et al. Building the field of health policy and systems research: social science matters. PLoS Med 2011; 8: e1001079.

8. Holmes SM, Greene JA, Stonington SD. Locating global health in social medicine. Glob Public Health 2014; 9: 475-80

9. Closser S, Finley EP. A New Reflexivity: Why Anthropology Matters in Contemporary Health Research and Practice, and How to Make It Matter More. Am Anthropol 2016; 118: 385-90

10. Storeng KT, Mishra A. Politics and practices of global health: critical ethnographies of health systems in context. Glob Public Health 2014; 9 : 858-64.

11. Norwegian Forum for Global Health Research. www.globalhealth.no/new-network-for-socialscience-in-norwegian-global-health/ (27.10.2016).

Mottatt 3.6. 2016, første revisjon innsendt 9.8. 2016, godkjent 4.10. 2016. Redaktør: Kaveh Rashidi. 